\title{
PENGARUH DISIPLIN KERJA, MOTIVASI KERJA DAN KOMITMEN ORGANISASI TERHADAP KINERJA PEGAWAI DINAS PEKERJAAN UMUM DAN PENATAAN RUANG KABUPATEN BARRU
}

\author{
Haedar $^{1}$, Mashur Rasak ${ }^{2}$, Muhammad Hidayat ${ }^{3}$ \\ Program Pasca Sarjana STIE Nobel Indonesia \\ Email : aqilah_ip@yahoo.com, mashur_razak@yahoo.co.id, hidayat2401@yahoo.com
}

\begin{abstract}
ABSTRAK
Penelitian ini bertujuan untuk mengetahui dan menganalisis (1) pengaruh disiplin kerja, motivasi kerja, dan komitmen organisasi secara parsial dan simultan terhadap kinerja pegawai pada Dinas Pekerjaan Umum dan Penataan Ruang Kabupaten Barru (2) variabel yang paling dominan berpengaruh terhadap kinerja pegawai.

Jenis penelitian ini merupakan deskriptif kuantitatif dengan sifat penelitian deskriptif explanatory research. Penelitian dilakukan di Dinas Pekerjaan Umum dan Penataan Ruang Kabupaten Barru selama 3 bulan. Populasi dalam penelitian ini berjumlah 81 orang pegawai Dinas Pekerjaan Umum dan Penataan Ruang Kabupaten Barru. Sampel dalam penelitian adalah keseluruhan jumlah populasi diambil sebagai sampel. Dengan demikian jumlah sampel sama dengan jumlah populasi (sensus atau sampel jenuh) sehingga sampel sebanyak 81 orang pegawai pada Dinas Pekerjaan Umum dan Penataan Ruang Kabupaten Barru. Metode analisis data yang digunakan dalam penelitian ini adalah model regresi linier berganda (multiple regression analysis).

Hasil penelitian menunjukkan bahwa (1) disiplin kerja, motivasi kerja, dan komitmen organisasi berpengaruh secara parsial dan simultan terhadap kinerja pegawai Dinas Pekerjaan Umum dan Penataan Ruang Kabupaten Barru (2) disiplin kerja merupakan variabel yang paling dominan berpengaruh terhadap kinerja pegawai.
\end{abstract}

Kata Kunci: disiplin kerja, motivasi kerja, komitmen organisasi, dan kinerja pegawai

\begin{abstract}
This research aims to determine and analyze (1) the effect of work discipline, work motivation, and organizational commitment partially and simultaneously toward the employee performance at the Public Works and Spatial Planning Office in Barru (2) the most dominant variable affects employee performance.

This type of research is descriptive quantitative with descriptive explanatory research. The research took place at the Public Works and Spatial Planning Office in Barru for 3 months. The population in this research was 81 employees at the Public Works and Spatial Planning Office in Barru. The sample is the entire population taken as a sample. Thus the number of samples is equal to the total population (census or saturated sample) so that a sample of 81 employees at the Public Works and Spatial Planning Office. The data analysis method used was a multiple linear regression model.

The results show that (1) work discipline, work motivation, and organizational commitment partially and simultaneously affect the employee performance at the Public Works and Spatial Planning Office in Barru (2) work discipline is the most dominant variable that affects employee performance.
\end{abstract}


Keywords: work discipline, work motivation, organizational commitment, and employee performance

\section{PENDAHULUAN}

\section{Latar Belakang}

Organisasi sebagai wadah untuk mencapai tujuan harus didukung oleh sumber daya manusia yang handal untuk melaksanakan pekerjaan. Hal ini sangat berkaitan utamanya dalam hal peningkatan kinerja. Suatu organisasi dikatakan berhasil dan berjalan secara efektif jika organisasi yang dimaksud dapat mencapai tujuan akhir yang menjadi cita-citanya.

Tujuan akhir dari suatu organisasi hanya bisa dicapai apabila sumber daya manusia yang terlibat di dalamnya dapat berperan secara aktif. Hal ini berlaku baik di organisasi pemerintah maupun swasta, karena sumber daya mansusia yang dalam hal ini disebut pegawai merupakan penggerak utama untuk menghasilkan kinerja yang baik.

Pegawai yang bekerja pada instansi pemerintah baik pada tingkat staf terendah maupun pada tingkat pimpinan, diharapkan memiliki kinerja yang baik sebagaimana tugasnya sebagai pelaksana pemerintahan. Meskipun disadari bahwa hal tersebut harus ditunjang oleh hal lainnya, tetapi kinerja pegawai yang baik sangat berperan dalam menentukan keberhasilan mencapai tujuan pada instansi pemerintah.

Diharapkan pegawai yang bekerja pada Dinas Pekerjaan Umum dan Penataan Ruang Kabupaten Barru memiliki disiplin yang baik dan dengan penuh tanggung jawab melaksanakan setiap pekerjaan untuk mencapai hasil yang maksimal. Pegawai yang disiplin akan memanfaatkan waktu dengan sebaik mungkin, patuh pada aturan baik yang berlaku di lingkup instansi maupun aturan yang berlaku secara umum. Akan tetapi pada kenyataannya masih banyak pegawai yang tidak mentaati aturan yang berlaku, misalnya terlambat datang, tidak masuk kantor tanpa alasan yang jelas dan sebagainya.

Disiplin menurut Hasibuan (2009), adalah sikap sadar dan kerelaan pegawai untuk taat pada aturan instansi dan norma sosial yang diberlakukan. Untuk pengertian yang lebih kecil dan secara luas digunakan, kedisiplinan memiliki arti yaitu aksi yang diterapkan untuk mengoreksi segala sikap maupun perilaku menyimpang terhadap pegawai. Sedangkan menurut Singodimedjo (Sopiah, 2013), disiplin kerja pegawai dipengaruhi oleh beberapa indikator, antara lain adalah ketegasan, waskat (pengawasan melekat), sanksi dan teladan pimpinan.

Motivasi pada dasarnya adalah dorongan untuk melakukan atau berbuat sesuatu untuk mencapai tujuan. Dorongan ini bisa berasal dari dalam diri maupun dari luar. Dengan dorongan yang baik dan tepat, seorang pegawai akan terpacu untuk mengembangkan diri dan menyelesaikan segala pekerjaan dengan hasil yang maksimal. Hal ini seringkali dipengaruhi oleh besar kecilnya tanggung jawab dan resiko, perasaan seberapa besar kemungkinan mengalami kemajuan dan tantangan dari pekerjaan, prestasi dan penghargaan atas hasil pekerjaan.

Motivasi kerja menurut Tella (Sopiah, 2013) adalah merupakan hal yang mendorong seseorang dalam bertindak untuk mencapai hasil yang diinginkan. Sedangkan menurut Muanandar (Nawawi, 2013) motivasi kerja adalah suatu proses dimana kebutuhan mendorong seseorang untuk melakukan serangkaian kegiatan yang mengarah ke tercapainya tujuan tertentu. Herzberg (Hasibuan, 2009), mengemukakan indikator motivasi kerja yang mempengaruhi kinerja, yang biasa juga disebut faktor 
intrinsik adalah tanggung jawab (responsibility), kemajuan (advancement), pekerjaan itu sendiri, Capaian (achievement) dan Pengakuan (recognition).

Pegawai yang memiliki komitmen yang tinggi akan merasa telah menjadi bagian dari instansi, menerima nilai dan mentaati aturan yang berlaku dalam instansi. Namun kenyataannya untuk mempertahankan pegawai yang memiliki kualitas dan partisipasi tinggi terhadap instansi kadang menjadi hal yang sulit. Sikap dan mental negatif pegawai menjadi pemicunya. Paradigma itu didukung oleh pendapat yang dikemukakan oleh McGregor (Saydam, 2000) yang mengatakan bahwa pada hakekatnya setiap orang senang untuk bebas dan tidak mau diperintah dan tidak senang diberikan tanggung jawab, senang bekerja dan terkadang lebih mengutamakan kepentingan sendiri, lebih memikirkan penghasilan yang tinggi tetapi beban kerja yang ringan, kecenderungan pegawai tidak mentaati aturan misalnya, malas datang apabila ada kegiatan rapat, datang tidak tepat waktu, menyelesaikan pekerjaan tidak tepat waktu.

Menurut Mathis dan Jackson (2011), arti penting dari komitmen organisasi adalah tingkat kepercayaan dan penerimaan tenaga kerja terhadap tujuan organisasi dan mempunyai keinginan untuk tetap ada di dalam organisasi. Menurut Lincoln dan Bashaw (Sopiah, 2013) terdapat tiga indikator yang mempengaruhi komitmen organisasi, yaitu kemauan karyawan, kesetiaan karyawan dan kebanggan karyawan.

Kinerja adalah tingkatan dalam hal mencapai hasil, atau bisa juga dilihat sebagai sebuah tahapan dalam proses terlaksananya pekerjaan agar mendapatkan hasil ataupun kinerja. Kinerja adalah tingkatan dalam hal mencapai hasil, atau bisa juga dilihat sebagai sebuah tahapan dalam proses terlaksananya pekerjaan agar mendapatkan hasil ataupun kinerja. Terdapat beberapa faktor yang berpengaruh terhadap kinerja pegawai diantaranya adalah seperti yang dikemukakan di atas adalah disiplin kerja, motivasi kerja dan komitmen organisasi.

Pengertian kinerja (Tika, 2011) telah dijelaskan oleh beberapa ahli manajemen, diantaranya adalah:

a. Handoko memberikan pengertian bahwa kinerja merupakan tahapan yang dilakukan organisasi untuk memberikan evaluasi ataupun penilaian kinerja karyawan.

b. Prawiro Suntoro mengutarakan bahwa kinerja adalah hasil kerja yang dihasilkan karyawan dalam suatu organisasi untuk mencapai tujuan dalam kurun waktu yang telah ditentukan.

Menurut Hasibuan (2009) ada beberapa hal yang menjadi indikator sehingga kinerja Pegawai dikatakan baik, yaitu kesetiaan, prestasi kerja, kedisiplinan, kreatifitas, kerja sama, kecakapan dan tanggung jawab.

Berdasarkan uraian di atas, maka peneliti tertarik untuk melakukan penelitian dengan judul: "Pengaruh Disiplin Kerja, Motivasi Kerja, dan Komitmen Organisasi terhadap Kinerja Pegawai Dinas Pekerjaan Umum dan Penataan Ruang Kabupaten Barru".

Kerangka konseptual penelitian ini digambarkan sebagai berikut: 
Gambar 1 : Kerangka Konseptual

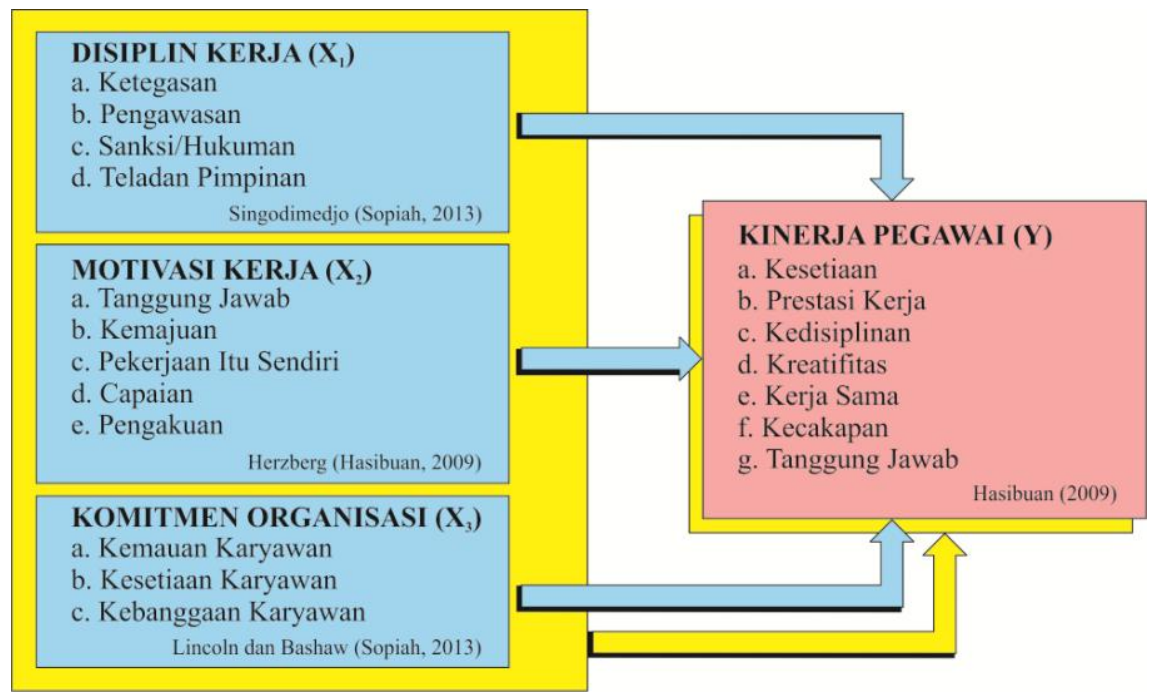

Hipotesis yang diberikan dalam penelitian ini adalah sebagai berikut:

1. Disiplin kerja, motivasi kerja dan komitmen organisasi berpengaruh positif signifikan secara sendiri-sendiri (parsial) terhadap kinerja pegawai pada Dinas Pekerjaan Umum dan Penataan Ruang Kabupaten Barru.

2. Disiplin kerja, motivasi kerja dan komitmen organisasi berpengaruh positif signifikan secara bersama-sama (simultan) terhadap kinerja pegawai pada Dinas Pekerjaan Umum dan Penataan Ruang Kabupaten Barru.

3. Variabel disiplin kerja yang paling berpengaruh terhadap kinerja pegawai pada Dinas Pekerjaan Umum dan Penataan Ruang Kabupaten Barru.

\section{METODE PENELITIAN}

Populasi dalam penelitian ini adalah seluruh pegawai pada Dinas Pekerjaan Umum dan Penataan Ruang yang berjumlah 81 orang. Karena jumlah populasi relatif kecil maka seluruh jumlah pegawai sebanyak 81 orang dijadikan sampel dalam penelitian ini atau yang biasa juga disebut metode sampling jenuh (sensus).

Pengukuran yang digunakan untuk mengukur instrumen variabel penelitian diperoleh melalui jawaban responden dengan memberikan tanda pada setiap kategori pernyataan yang disusun berdasarkan skala Likert dengan rentang 5 level. Setiap jawaban responden akan diberi skor. Skor yang diberikan pada setiap jawaban responden adalah (SS) sangat setuju skor 5, (S) setuju skor 4, (R) ragu-ragu skor 3, (TS) tidak setuju skor 2 dan (STS) sangat tidak setuju skor 1. Teknik pengumpulan data menggunakan daftar pertanyaan (angket) yang telah disiapkan untuk seluruh responden dan penggunaan dokumen untuk melengkapi data yang belum lengkap pada data primer

Variabel bebas yang digunakan adalah disiplin kerja $\left(\mathrm{X}_{1}\right)$, motivasi kerja $\left(\mathrm{X}_{2}\right)$ dan komitmen organisasi $\left(\mathrm{X}_{3}\right)$. Sedangkan variabel terikat yang digunakan adalah kinerja (Y).

Metode analisis yang digunakan untuk penelitian ini adalah metode analisis regresi linier sederhana. Analisis data dilakukan melalui beberapa tahapan seperti uji validitas, uji reliabilitas, uji asumsi klasik yang terdiri uji multikolinearitas, heteroskedastitas dan normalitas regresi. Pengujian hipotesis dilakukan melalui analisis regresi sederhana dan uji $\mathrm{t}$ maupun uji $\mathrm{F}$, variabel yang paling dominan 
dengan menggunakan nilai beta dan koefisien determinasi. Untuk analisis data ini menggunakan program pengolahan data yaitu program SPSS..

\section{HASIL PENELITIAN DAN PEMBAHASAN}

\section{Hasil Penelitian}

Uji validitas dilakukan dengan mengkorelasikan skor setiap item dengan skor total dari masing-masing atribut, formulasi koefisien yang digunakan adalah Pear-son Product Moment Test dengan program SPSS. Dari uji validitas yang, maka didapatkan hasil seluruh item variabel bebas dan variabel terikat menunjukkan sahih atau valid, dengan nilai Corrected Item Total Correlation positif di atas angka 0,2185.

Pengujian reliabilitas dengan internal concistency dilakukan dengan cara mengujikan instrumen hanya sekali saja, kemudian data yang diperoleh dianalisis dengan menggunakan Cronbach's Alpha.

Menurut Zeithaml Berry, dengan menggunakan reliabilitas Cronbach's Alpha > 0,60, maka koefisien reliabilitas pada penelitian ini dapat diterima.

Uji multikolinearitas berfungsi untuk mendeteksi ada atau tidak adanya gejala multikolinearitas menggunakan besaran nilai VIF (Variance Inflation Factor) yang diolah menggunakan alat bantu program analisa data dimana nilai VIF dari masingmasing variabel bebas. Jika nilai VIF di bawah 10 dan nilai toleransi di atas 0,1 maka tidak terjadi multikolinearitas. Berdasarkan hasil olah data menggunakan SPSS, ketiga variabel mempunyai nilai tolerance di atas 0,1 dan nilai VIF di bawah 10 , sehingga tidak terjadi multikolinearitas pada model regresi penelitian ini.

Untuk menguji apakah variabel pengganggu mempunyai varian yang sama atau tidak maka dilakukan uji heterokedastisitas. Dalam hasil olah data SPSS dihasilkan sebaran gambar yang tidak teratur sehingga dalam penelitian ini bisa dikatakan tidak mengandung heterokedastisitas.

Untuk mengetahui hasil perhitungan bersifat normal dapat dilakukan dengan melihat grafik histogram dan grafik scatter plot yang membandingkan antara data observasi dengan distribusi yang mendekati distribusi normal. Dalam penelitian ini terlihat bahwa untuk pengujian normalitas menunjukkan sifat normal. Distribusi normal juga ditunjukkan dengan diagram probability plot yang membentuk pola garis lurus dalam grafik scatter plot hasil olah data SPSS.

Teknik analisis data yang dipergunakan dalam penelitian ini menggunakan teknik analisis regresi linear berganda dengan asumsi persamaannya sebagai berikut :

$$
\mathrm{Y}=\mathrm{b}_{0}+\mathrm{b}_{1} \mathrm{X}_{1}+\mathrm{b}_{2} \mathrm{X}_{2}+\mathrm{b}_{3} \mathrm{X}_{3}+\mathrm{e}
$$

Dengan menggunakan alat bantu program analisa data maka diperoleh nilai koefisien regresi masing-masing variabel $\mathrm{X}_{1}, \mathrm{X}_{2}$, dan $\mathrm{X}_{3}$, dapat dijelaskan sebagai berikut :

Tabel 1 : Hasil Perhitungan Regresi

\begin{tabular}{c|c|c}
\hline Model & B & Std. Error \\
\hline Constanta & 9,550 & 1,777 \\
\hline Disiplin Kerja $\left(\mathrm{X}_{1}\right)$ & 0,432 & 0,142 \\
\hline Motivasi Kerja $\left(\mathrm{X}_{2}\right)$ & 0,397 & 0,108 \\
\hline Komitmen Organisasi $\left(\mathrm{X}_{3}\right)$ & 0,425 & 0,176 \\
\hline
\end{tabular}

Berdasarkan hasil print out SPSS diperoleh koefisien dalam perhitungan regresi di atas, maka persamaan regresinya menjadi : $Y=9,550+0,432 X_{1}+0,397 X_{2}+0,425 X_{3}$. 
Formulasi regresi linear berganda di atas diperoleh nilai konstanta sebesar 9,550 mempunyai pengertian bahwa jika skor meliputi disiplin kerja, motivasi kerja dan komitmen organisasi nilainya tetap/konstan maka kinerja pegawai Dinas Pekerjaan Umum dan Penataan Ruang Kabupaten Barru mempunyai nilai sebesar 9,550.

Nilai koefisien regresi disiplin kerja $\left(\mathrm{X}_{1}\right)$ sebesar 0,432 ada pengaruh positif disiplin kerja terhadap kinerja pegawai Dinas Pekerjaan Umum dan Penataan Ruang Kabupaten Barru sebesar 0,432 sehingga apabila skor disiplin kerja naik 1 poin maka akan diikuti dengan kenaikan skor kinerja pegawai Dinas Pekerjaan Umum dan Penataan Ruang Kabupaten Barru sebesar 0,432 poin.

Nilai koefisien regresi motivasi kerja $\left(\mathrm{X}_{2}\right)$ sebesar 0,397 berarti ada pengaruh positif motivasi kerja kerja terhadap kinerja pegawai Dinas Pekerjaan Umum dan Penataan Ruang Kabupaten Barru sebesar 0,397 sehingga apabila skor motivasi kerja kerja naik 1 poin maka akan diikuti dengan kenaikan skor kinerja pegawai Dinas Pekerjaan Umum dan Penataan Ruang Kabupaten Barru sebesar 0,397 poin.

Nilai koefisien regresi komitmen organisasi $\left(\mathrm{X}_{3}\right)$ sebesar 0,425 berarti ada pengaruh positif komitmen organisasi terhadap kinerja pegawai Dinas Pekerjaan Umum dan Penataan Ruang Kabupaten Barru sebesar 0,425 sehingga apabila skor komitmen organisasi naik 1 poin maka akan diikuti dengan kenaikan skor kinerja pegawai Dinas Pekerjaan Umum dan Penataan Ruang Kabupaten Barru sebesar 0,425 poin.

Untuk menguji variabel secara parsial atau sendiri-sendiri variabel independen (X) terhadap variabel dependen (Y) dapat digunakan uji t. Ini dapat dilihat dalam hasil analisa pengolahan data yang tertuang dalam Tabel 1 berikut :

Tabel 1 : Hasil Uji T

\begin{tabular}{l|c|c|c|c}
\hline \multicolumn{1}{c|}{ Model } & T Hitung & Sig & T Tabel & Keterangan \\
\hline \hline \multicolumn{1}{c|}{ Constanta } & 5,373 & 0,000 & & \\
\hline Disiplin Kerja $\left(\mathrm{X}_{1}\right)$ & 3,055 & 0,003 & 1,665 & Berpengaruh \\
\hline Motivasi Kerja $\left(\mathrm{X}_{2}\right)$ & 3,668 & 0,000 & 1,665 & Berpengaruh \\
\hline Komitmen Organisasi $\left(\mathrm{X}_{3}\right)$ & 2,409 & 0,018 & 1,665 & Berpengaruh \\
\hline
\end{tabular}

Oleh karena $t_{\text {hitung }}$ sebesar 3,055 lebih besar dibandingkan dengan $t$ tabel sebesar 1,665 yang berarti variabel disiplin kerja berpengaruh terhadap kinerja pegawai Dinas Pekerjaan Umum dan Penataan Ruang Kabupaten Barru.

Oleh karena $t_{\text {hitung }}$ sebesar 3,668 lebih besar dibandingkan dengan $t$ tabel sebesar 1,665 yang berarti variabel motivasi kerja kerja berpengaruh terhadap kinerja pegawai Dinas Pekerjaan Umum dan Penataan Ruang Kabupaten Barru.

Oleh karena $t_{\text {hitung }}$ sebesar 2,409 lebih besar dibandingkan dengan $t$ tabel sebesar 1,665 yang berarti variabel komitmen organisasi berpengaruh terhadap kinerja pegawai Dinas Pekerjaan Umum dan Penataan Ruang Kabupaten Barru .

Uji F berfungsi untuk menguji variabel disiplin kerja, motivasi kerja dan komitmen organisasi, apakah dari ketiga variabel yang diteliti mempengaruhi secara simultan terhadap kinerja pegawai Dinas Pekerjaan Umum dan Penataan Ruang Kabupaten Barru . Analisa dilakukan dengan menggunakan alat bantu program pengolahan data yang dapat dijelaskan dalam Tabel 2 berikut : 
Tabel 2 : Hasil Uji F

\begin{tabular}{l|c|c|c|l}
\hline \multicolumn{1}{c|}{ Model } & Sum of Squares & F Hitung & F Tabel & Keterangan \\
\hline Regression & 9,542 & 38,178 & 2,72 & Berpengaruh \\
\cline { 1 - 3 } Residual & 6,544 & & & Secara \\
Total & 16,086 & & & Simultan \\
\hline
\end{tabular}

Oleh karena nilai $\mathrm{F}_{\text {hitung }}$ sebesar 38,178 , berarti variabel bebas/independen $(\mathrm{X})$ yang meliputi disiplin kerja, motivasi kerja dan komitmen organisasi secara simultan berpengaruh terhadap kinerja pegawai Dinas Pekerjaan Umum dan Penataan Ruang Kabupaten Barru bisa dikatakan signifikan karena dari pengujian menunjukkan bahwa hasil $F_{\text {hitung }}=38,178$ lebih besar dari $F_{\text {tabel }}=2,72$ atau bisa dikatakan $\mathrm{H}_{\mathrm{o}}$ ditolak dan $\mathrm{H}_{1}$ diterima.

Koefisien B dipergunakan untuk menguji variabel-variabel bebas/independen (X) yang memiliki pengaruh paling dominan terhadap variabel terikat/dependen (Y). Variabel yang paling dominan berpengaruh adalah variabel yang memiliki koefisien beta standardized tertinggi. Hasil pengolahan data menggunakan SPSS dapat dilihat pada tabel berikut ini :

Tabel 3 : Hasil Koefisien B

\begin{tabular}{l|c|c|c|c}
\hline \multirow{2}{*}{ Model } & \multicolumn{2}{|c|}{$\begin{array}{c}\text { Unstandardized } \\
\text { Coeficients }\end{array}$} & $\begin{array}{c}\text { Standardized } \\
\text { Coeficients }\end{array}$ & \multirow{2}{*}{ Keterangan } \\
\cline { 2 - 4 } & $\mathrm{B}$ & Std. Error & Beta & \\
\hline (Constant) & 9,550 & 1,77 & & \\
\hline Disiplin Kerja (X1) & 0,432 & 0,142 & 0,282 & Paling Berpengaruh \\
\hline Motivasi Kerja (X2) & 0397 & 0,108 & 0,361 & \\
\hline Komitmen Organisasi (X3) & 0,425 & 0,176 & 0,255 & \\
\hline
\end{tabular}

Berdasarkan nilai koefesien $\mathrm{B}$ pada tabel di atas, maka dengan nilai koefisein $\mathrm{B}$ sebesar 0,432 variabel disiplin kerja yang memiliki pengaruh paling besar terhadap kinerja pegawai Dinas Pekerjaan Umum dan Penataan Ruang Kabupaten Barru.

Penelitian ini juga menemukan besarnya pengaruh variabel bebas terhadap variabel terikat yang dapat dilihat dari nilai koefisien determinasi ( $\mathrm{R}$ square) dan dapat dilihat pada tabel berikut:

Tabel 4 : Hasil Koefisen Determinasi

\begin{tabular}{c|c|c|c}
\hline Model & R & R Square & Keterangan \\
\hline 1 & 0,773 & 0,598 & Memiliki Pengaruh Sebesar 59,8\% \\
\hline
\end{tabular}

Nilai koefisien determinasi ( $\mathrm{R}$ square) sebesar 0,598 yang dapat diartikan bahwa variabel bebas/independen (X) yang meliputi disiplin kerja, motivasi kerja dan komitmen organisasi mempunyai kontribusi terhadap kinerja pegawai Dinas Pekerjaan Umum dan Penataan Ruang Kabupaten Barru sebesar 59,8\%, sedangkan sisanya sebesar $40,2 \%$ dipengaruhi oleh variabel lain yang tidak termasuk dalam penelitian ini.

\section{Pembahasan Hasil Penelitian}

Berdasarkan hasil hipotesis penelitian diperoleh bahwa disiplin kerja $\left(\mathrm{X}_{1}\right)$ berpengaruh secara signifikan terhadap kinerja pegawai $(\mathrm{Y})$, dengan nilai koefisien 
regresi sebesar 0,432. Jika disiplin kerja mengalami peningkatan sebesar satu satuan maka kinerja pegawai juga akan mengalami kenaikan sebesar 0,432 dengan asumsi bahwa variabel bebas lainnya memiliki nilai yang tetap.

Menurut Sutrisno (2009), menyatakan disiplin kerja menunjukkan suatu kondisi atau sikap hormat yang ada pada diri karyawan terhadap peraturan dan ketepatan perusahaan. Pendapat ini juga didukung oleh Handoko (2001), yang menyatakan bahwa disiplin adalah kegiatan manajemen dalam hal menjalankan standar organisasional.

Hasil uji $t$ dalam penelitian ini menunjukkan hasil bahwa nilai $t_{\text {hitung }} 3,055>t_{\text {tabel }}$ 1,665 dan nilai signifikansi sebesar 0,003. Berdasarkan hasil yang diperoleh maka $\mathrm{H}_{0}$ ditolak dan $\mathrm{H}_{1}$ diterima untuk variabel disiplin kerja, maka secara parsial variabel disiplin kerja berpengaruh terhadap kinerja pegawai. Hasil penelitian ini sejalan dengan penelitian yang dilakukan oleh Rico D. Pakpahan (2017), yang berjudul "Pengaruh Disiplin Kerja dan Lingkungan Kerja terhadap Kinerja Karyawan (Studi Kasus pada Karyawan CV. Hamparan Seaga)". Hasil penelitiannya menyimpulkan bahwa disiplin kerja berpengaruh positif dan signifikan terhadap kinerja karyawan.

Hasil hipotesis penelitian menunjukkan bahwa variabel motivasi kerja $\left(\mathrm{X}_{2}\right)$ secara signifikan memiliki pengaruh terhadap kinerja pegawai (Y), dengan nilai koefisien regresi sebesar 0,397. Dengan demikian apabila motivasi kerja mengalami peningkatan sebesar satu satuan maka kinerja pegawai juga akan mengalami kenaikan sebesar 0,397 dengan asumsi variabel bebas lainnya memiliki nilai yang tetap.

Menurut Sedarmayanti (2012), motivasi kerja adalah kesediaan mengeluarkan tingkat upaya yang tinggi ke arah tujuan organisasi yang dikondisikan dengan kemampuan upaya tersebut untuk memenuhi kebutuhan individual. Dengan demikian, apabila pegawai memiliki motivasi kerja yang baik maka pegawai tersebut akan lebih kuat dan selanjutkan akan memiliki kinerja yang baik dengan penuh komitmen hingga tujuan organisasi dapat tercapai. Mendukung pendapat ini, Buhler (Sedarmayanti, 2012) pun mengemukakan bahwa karena dorongan untuk bekerja ini sangat menentukan bagi tercapainya suatu tujuan, maka seseorang harus mampu memunculkan motivasi kerja sebaik mungkin bagi para karyawan dalam perusahaan, karena motivasi memiliki kaitan yang sangat erat dengan timbulnya suatu kecenderungan untuk melakukan berbagai usaha dalam hal mencapai tujuan. Melalui analisis uji t penelitian mendapatkan hasil yang menunjukkan bahwa nilai $\mathrm{t}_{\text {hitung }} 3,668>\mathrm{t}_{\text {tabel }}$ 1,665 dan nilai signifikan sebesar 0,000. Berdasarkan hasil yang diperoleh maka $\mathrm{H}_{0}$ ditolak dan $\mathrm{H}_{1}$ diterima, dengan demikian maka variabel motivasi kerja secara parsial memiliki pengaruh terhadap kinerja pegawai. Hasil penelitian ini mendukung penelitian-penelitian terdahulu, salah satunya adalah penelitian dari Muhammad Taufiek Rio Sanjaya, (2015) tentang "Pengaruh Disiplin Kerja dan Motivasi Kerja terhadap Kinerja Karyawan pada Hotel Ros In Yogyakarta". Kesimpulan dari penelitian ini adalah bahwa secara parsial disiplin kerja berpengaruh postitif terhadap kinerja karyawan pada Hotel Ros In Yogyakarta.

Hasil hipotesis penelitian menunjukkan bahwa komitmen organisasi (X3) memiliki pengaruh signifikan terhadap kinerja pegawai (Y) dengan nilai koefisien regresi sebesar 0,425. Jadi jika komitmen organisasi mengalami peningkatan sebesar satu tingkatan maka kinerja pegawai akan mengalami kenaikan sebesar 0,425 dengan asumsi variabel bebas lainnya bernilai tetap.

Mathis dan Jackson (2011), mengemukakan bahwa komitmen organisasi adalah derajat dimana karyawan percaya dan menerima tujuan-tujuan organisasi dan tetap 
mempertahankan diri menjadi bagian dari organisasi. Bagi organisasi, komitmen organisasi dibutuhkan untuk menjaga dan memelihara kekompakan antar pegawai sehingga pegawai akan merasa menjadi bagian dari organisasi itu sendiri. Pendapat ini juga didukung oleh Steers dalam Sopiah (2013) yang mengemukakan bahwa komitmen organisasi sebagai sebuah perasaan mengidentifikasi berupa rasa percaya dan menerima dengan kuat tujuan dan nilai-nilai organisasi, keterlibatan berupa perilaku bersedia agar bisa berusaha sebaik mungkin untuk mencapai tujuan organisasi, dan loyalitas berupa kemauan kuat untuk tetap bertahan menjadi bagian dari organisasi.

Hasil penelitian dapat dibuktikan melalui analisis uji t yang menunjukkan nilai $t_{\text {hitung }} t_{\text {hitung }} 2,409>t_{\text {tabel }} 1,665$ dan nilai signifikan sebesar 0,018. Berdasarkan hasil yang diperoleh maka $\mathrm{H}_{0}$ ditolak dan $\mathrm{H}_{1}$ diterima untuk variabel komitmen organisasi, dengan demikian maka variabel komitmen organisasi secara parsial memiliki pengaruh terhadap kinerja pegawai.

Hasil penelitian ini mendukung penelitian-penelitian terdahulu, salah satunya adalah penelitian dari Adrianus Adhi Nugroho (2017) tentang "Pengaruh Motivasi Kerja dan Komitmen Organisasional terhadap Kinerja Pegawai (Studi pada Yayasan Budi Bakti Karya MASF Balikpapan Kalimantan Timur)". Hasil penelitian menyimpulkan bahwa komitmen organisasional secara sendiri memiliki pengaruh signifikan terhadap kinerja pegawai.

Hasil penelitian melalui pengujian secara simultan (Uji F) menunjukkan bahwa variabel bebas yang terdiri dari disiplin kerja, motivasi kerja dan komitmen organisasi memiliki pengaruh secara simultan terhadap kinerja pegawai pada Dinas Pekerjaan Umum dan Penataan Ruang Kabupaten Barru. Hasil pengujian menunjukkan bahwa hasil $\mathrm{F}_{\text {hitung }}=38,178$ lebih besar dari $\mathrm{F}_{\text {tabel }}=2,72$.

Berdasarkan hasil penelitian Koefisien Determinasi $\left(\mathrm{R}^{2}\right)$ diperoleh nilai sebesar $0.598(59,8 \%)$ dapat diartikan bahwa variasi variabel bebas (disiplin kerja, motivasi kerja dan komitmen organisasi) memiliki pengaruh sebesar $59,8 \%$ terhadap variabel terikat (kinerja pegawai). Berarti terdapat hubungan yang cukup kuat antara variabel bebas terhadap variabel terikat, hal ini dapat dibuktikan dengan nilai $\mathrm{R}$ sebesar 0,773 $(77,3 \%)$.

Hasil penelitian meunjukkan bahwa nilai konstanta kinerja pegawai pada model regresi sebesar 9,550 artinya jika nilai variabel bebas $(\mathrm{X})$ nilainya 0 maka variabel terikat (Y) nilainya sebesar 9,550. Koefisien regresi ketiga variabel bebas disiplin kerja $\left(\mathrm{X}_{1}\right)$ dan motivasi kerja $\left(\mathrm{X}_{2}\right)$ dan komitmen organisasi $\left(\mathrm{X}_{3}\right)$ bernilai positif artinya terdapat hubungan yang berpengaruh positif, jika masing-masing variabel bebas (X) mengalami kenaikan sebesar satu satuan maka variabel terikat (Y) akan mengalami peningkatan sebesar nilai koefisien masing-masing variabel bebas disiplin kerja $\left(\mathrm{X}_{1}\right)$, motivasi kerja $\left(\mathrm{X}_{2}\right)$ dan komitmen organisasi $\left(\mathrm{X}_{3}\right)$.

Hasil penelitian ini mendukung penelitian-penelitian terdahulu, salah satunya adalah penelitian dari Triyaningsih, (2014) tentang "Analisis Pengaruh Disiplin Kerja, Motivasi Kerja dan Komitmen Organisasi terhadap Kinerja Karyawan Universitas Slamet Riyadi Surakarta". Hasil penelitian menyimpulkan bahwa disiplin kerja, motivasi kerja, dan komitmen organisasi memiliki pengaruh signifikan secara simultan terhadap kinerja karyawan.

Mathis dan Jackson (2011), mengemukakan bahwa sistem kinerja pegawai akan mengusahakan untuk mengidentifikasi, memberikan dorongan, 
mengevaluasi/mengukur, meningkatkan, dan memberikan penghargaan terhadap kinerja karyawan.

Hasil penelitian melalui hasil koefisien B menunjukkan bahwa variabel disiplin kerja memiliki pengaruh paling dominan terhadap kinerja pegawai pada Dinas Pekerjaan Umum dan Penataan Ruang Kabupaten Barru dengan nilai koefisien B tertinggi sebesar 0,432. Hasil penelitian ini mendukung penelitian-penelitian terdahulu, salah satunya adalah penelitian dari Khairul Imamul (2017) tentang "Pengaruh Disiplin, Komitmen Organisasi terhadap Kinerja Pegawai Dinas Pemberdayaan Perempuan, Perlindungan Anak, Pengendalian Penduduk dan Keluarga Berencana (DP3A P2KB) Kota Batu". Hasil penelitian menyimpulkan bahwa variabel disiplin kerja yang paling dominan berpengaruh terhadap kinerja pegawai.

\section{SIMPULAN DAN SARAN}

\section{Simpulan}

Berdasarkan hasil penelitian maka didapatkan hasil bahwa disiplin kerja, motivasi kerja dan komitmen organisasi berpengaruh signifikan secara parsial dan simultan terhadap kinerja pegawai Dinas Pekerjaan Umum dan Penataan Ruang Kabupaten Barru. Sedangkan variabel yang paling dominan berpengaruh adalah disiplin kerja.

Saran

Berdasarkan hasil kesimpulan, maka disarankan agar pihak Dinas Pekerjaan Umum dan Penataan Ruang Kabupaten Barru untuk memperhatikan disiplin kerja, motivasi kerja dan komitmen organisasi karena terbukti dapat meningkatkan kinerja pegawai.

\section{DAFTAR PUSTAKA}

Adhi Nugroho, Adrianus. 2017. Pengaruh Motivasi Kerja dan Komitmen Organisasional terhadap Kinerja Pegawai (Studi pada Yayasan Budi Bakti Karya MASF Balikpapan Kalimantan Timur). Universitas Sanata Dharma Yogyakarta. Yogyakarta: Skripsi.

Alwi, Safaruddin. 2011. Manajemen Sumber Daya Manusia Keunggulan Kompetitif. Yogyakarta : Penerbit BPFE.

D. Pakpahan, Rico. 2017. Pengaruh Disiplin Kerja dan Lingkungan Kerja terhadap Kinerja Karyawan (Studi Kasus pada Karyawan CV. Hamparan Seaga). Universitas Negeri Yogyakarta. Yogyakarta: Skripsi.

Ghozali, Imam. 2011. Aplikasi Analisis Multivariate Dengan Program SPSS. Edisi Keempat. Semarang: Penerbit BP-Universitas Diponegoro.

Handoko, T. Hani. 2011. Manajemen Personalia dan Sumber Daya Manusia. Yogyakarta: Penerbit BPFE.

Hasibuan, Melayu. 2009. Manajemen Sumber Daya Manusia. Jakarta: Penerbit Bumi Aksara.

Imamul, Khairul. 2017. Pengaruh Disiplin, Komitmen Organisasi terhadap Kinerja Pegawai Dinas Pemberdayaan Perempuan, Perlindungan Anak, Pengendalian 
Penduduk dan Keluarga Berencana (DP3A P2KB) Kota Batu. Universitas Islam Malang. Malang: Skripsi.

Mathis, Robert L dan Jhon H. Jackson. 2011. Human Resource Management, Manajemen Sumber Daya Manusia. Jakarta: Penerbit Salemba Empat.

Nawawi, Hadari. 2013. Manajemen Sumber Daya Manusia. Yogyakarta: Penerbit Gadjah Mada University Press.

Sedarmayanti. 2012. Manajemen Sumber Daya Manusia: Reformasi Birokrasi dan Manajemen Pegawai Negeri Sipil. Cetakan Pertama. Bandung: Penerbit PR. Refika Aditama.

Singodimedjo, Markum. 2012. Manajemen Sumber Daya Manusia. Surabaya: Penerbit SMMA.

Sopiah, 2013. Perilaku Organisasional. Cetakan Kedua. Yogyakarta: Penerbit CV. Andi Offset.

Taufiek Rio Sanjaya, Muhammad. 2015. Pengaruh Disiplin Kerja dan Motivasi Kerja terhadap Kinerja Karyawan pada Hotel Ros In Yogyakarta. Universitas Negeri Yogyakarta. Yogyakarta: Skripsi.

Tika, Moh. Pandu. 2011. Budaya Organisasi dan Peningkatan Kinerja Organisasi. Jakarta: Penerbit Bumi Aksara.

Triyaningsih, 2014. Analisis Pengaruh Disiplin Kerja, Motivasi Kerja dan Komitmen Organisasi terhadap Kinerja Karyawan Universitas Slamet Riyadi Surakarta. Universitas Slamet Riyadi Surakarta. Surakarta : Skripsi 